\title{
PENGGUNAAN MEDIA MOBIL MAINAN UNTUK MENINGKATKAN PEMAHAMAN KONSEP OPERASI HITUNG BILANGAN BULAT
}

\author{
Dyah Tri Wahyuningtyas \\ Universitas Kanjuruhan Malang
}

\begin{abstract}
Abstrak: Penggunaan Media Mobil Mainan untuk Meningkatkan Pemahaman Konsep Operasi Hitung Bilangan Bulat. Penelitian ini bertujuan mendeskripsikan penggunaan media mobil mainan untuk meningkatkan pemahaman konsep operasi hitung bilangan bulat. Media mobil mainan digunakan untuk mengkonkretkan konsep operasi hitung bilangan bulat, khususnya penjumlahan dan pengurangan bilangan bulat. Metode yang digunakan yaitu penelitian tindakan kelas dengan subjek penelitian 33 siswa kelas 1V SDN Mojolangu 4 Malang. Produk penelitian ini berupa media mobil mainan serta langkah penggunaannya. Hasil penelitian menunjukkan penggunaan media mobil mainan mempermudah siswa dalam memahami konsep operasi hitung bilangan bulat dan pemahaman siswa meningkat.
\end{abstract}

Kata Kunci: media mobil mainan, pemahaman konsep, operasi hitung bilangan bulat.

\begin{abstract}
Using Toy Car Media to Improve Students Comprehension on Integer Operation. This research aim is to give a description about how using toy car media to Improve Students Comprehension on Integer Operation. Toy car media used to concretized the integer operation concept. The method is using PTK with 33 students of $4^{\text {th }}$ grades in SDN Mojolangu 4 Malang research subject. The product is toy car media and its procedures. The result showed increase using toy car media ease students to understand integer operation concept so that students comprehension improve.
\end{abstract}

Keywords: toy car media, comprehention concept, integer operation.

Kurikulum SD pada Depdiknas 2007 diketahui bahwa pembelajaran matematika membangun kemampuan dasar yang kokoh tentang pemahaman konsep, ide-ide, gagasan, aturan-aturan, logika dalam mate-matika, menggunakan penalaran dan pembuktian untuk memecahkan masalah kehidupan (Depdiknas, 2007). Sehingga siswa diharapan memiliki sikap disiplin, ulet, rasa ingin tahu dan percaya diri. Tetapi sampai saat ini masih banyak siswa yang menganggap bahwa pelajaran matematika sulit karena bersifat abstrak, penuh dengan angka dan rumus.

Bilangan adalah bagian dari matematika yang paling sering digunakan seperti bilangan asli, cacah, bulat dan pecahan. Bilangan bulat terdiri dari bilangan bulat positif, bilangan bulat negatif, dan bilangan 0 (Muhsetyo dkk :2007). Kita sering menggunakan bilangan bulat, baik secara langsung (dengan lambang bilangan bulat) atau secara tidak langsung (dengan menggunakan istilah atau kata-kata). Contoh bilangan bulat dengan kata dalam kehidupan sehari-hari seperti maju 3 langkah dapat ditulis +3 , mundur 2 langkah dapat ditulis -2 , menang 5 poin dapat ditulis +5 , serta rugi 500 rupiah dapat ditulis -500 dan sebagainya.

Salah satu kompetensi dasar SD/MI kelas IV semester II berdasarkan KTSP 2006 pada pelajaran matematika adalah bilangan bulat. Muhsetyo dkk (2007:1.29-1.32) menyebutkan permasalahan dan pembelajaran bilangan bulat di sekolah diantaranya: penggunaan garis bilangan yang menyimpang dari prinsipnya, masih banyak guru dan siswa yang tidak dapat membedakan tanda “_" atau “+” sebagai operasi hitung dengan tanda “_." atau “+” sebagai jenis suatu bilangan, serta sulit memberikan penjelasan bagaimana melakukan operasi hitung pada bilangan bulat secara konkrit maupun abstrak (tanpa menggunakan alat bantu).

Berdasarkan hasil observasi yang dilaksanakan di SD Negeri Mojolangu 4 Malang, diperoleh fakta bahwa (1) siswa masih kurang paham tentang arah dan pergerakan operasi hitung bilangan bulat pada garis 
bilangan, (2) mengubah operasi hitung bilangan bulat pada garis bilangan ke kalimat matematika dan (3) sebagian siswa masih melakukan kesalahan pada pengerjaan operasi penjumlahan bilangan bulat positif dan negatif.

Sejauh ini, penyebab utamanya diduga karena belum ada media yang tepat digunakan untuk membantu siswa memahami konsep operasi hitung bilangan bulat. Biasanya pada pembelajaran operasi bilangan bulat untuk membantu pemahaman siswa hanya dengan menggunakan garis bilangan. Siswa yang tidak paham hanya mendapatkan konsep abstrak karena tidak dapat membayangkan penggunaan garis bilangan pada operasi hitung bilangan bulat.

Salah satu alternatif media yang dapat digunakan untuk membantu mengkonkretkan garis bilangan pada operasi hitung bilangan bulat adalah dengan membuat lintasan seperti garis bilangan. Untuk mengetahui pergerakan dan arahnya dapat menggunakan mainan kesukaan anak, misalnya mobil mainan. Berdasarkan teori belajar menurut Bruner, Piaget dan Vygotsky yang menyatakan bahwa pada siswa usia SD dalam proses belajarnya mereka masih harus melakukan kegiatan fisik dengan benda konkrit. Oleh karena itu, peneliti mencoba menggunakan media mobil mainan yang diduga dapat meningkatkan pemahaman konsep operasi hitung bilangan bulat pada siswa kelas IV SDN Mojolangu 4 Malang.

Media mobil mainan merupakan media permainan yang dapat dimanfaatkan dalam pembelajaran matematika khususnya dalam memahami operasi hitung bilangan bulat pada garis bilangan. Media mobil mainan ini terdiri dari balok kayu yang berfungsi sebagai lintasannya dan mobil-mobilan. Pada balok kayu dituliskan bilangan bulat sebagai satuannya, misalnya panjang balok 11 satuan dapat ditulis $-5,-4,-3,-2,-1,0,1,2,3,4,5$.

Media mobil mainan ini dapat mengarahkan kemampuan siswa dalam menentukan arah dan pergerakan satuan bilangan bulat pada garis bilangan. Bentuk dan warna media mobil mainan yang menarik dapat merangsang kemampuan motorik siswa sehingga siswa tidak akan mudah lupa dengan apa yang pernah dilihat dan dialami. Oleh karena itu dengan penggunaan media mobilmobilan ini diharapkan siswa dapat mengaitkan dan memahami operasi hitung bilangan bulat pada garis bilangan.
Tujuan penelitian ini yaitu mendeskripsikan penggunaan media mobil mainan untuk meningkatkan pemahaman konsep operasi hitung bilangan bulat siswa kelas IV SDN Mojolangu 4 Malang. Pemahaman siswa yang hendak dicapai yaitu dapat menggambarkan arah dan satuan operasi bilangan bulat pada garis bilangan atau media mobil mainan, dapat menentukan operasi hitung bilangan bulat pada garis bilangan, dan dapat menyelesaikan soal operasi penjumlahan dan pengurangan: dua bilangan bulat positif, bilangan bulat positif dan negatif dan dua bilangan bulat negatif tanpa menggunakan garis bilangan atau media mobil mainan. Pada penelitian ini kriteria keberhasilan pemahaman siswa dikatakan meningkat jika $\geq 75 \%$ siswa mencapai skor minimal 75 (skor tertinggi 100).

\section{LANDASAN TEORI}

Pada umumnya siswa sekolah dasar (SD) berumur 7-12 tahun, menurut Piaget (Siegler dkk, 2006) anak usia 7-12 tahun berada pada tahap operasional konkrit. Pada tahap operasional konkrit anak masih belum berpikir seperti orang dewasa sehingga mengalami kesulitan dengan pemikiran abstrak. Tahap perkembangan mental menurut Bruner (1965:11) yaitu: (1) Enactive, pada tahap ini anak-anak belajar dengan menggunakan atau memanipulasi objek atau benda secara langsung, (2) Ikonic, pada tahap ini kegiatan anak mulai mengaitkan mental yang merupakan gambaran dari objek. Dalam tahap ini, anak sudah dapat memanipulasi dengan menggunakan gambaran dari obyek, (3) Symbolic, pada tahap ini merupakan tahap memanipulasi simbol-simbol secara langsung.

Konsep operasi hitung bilangan bulat ini masih bersifat abstrak, sehingga dibutuhkan media pembelajaran untuk membantu mengkonkritkannya. Media adalah segala sesuatu yang dapat digunakan untuk menyampaikan pesan sehingga dapat merangsang pikiran, minat dan perhatian siswa (Sadiman, 2008). Penggunaan media dalam proses pembelajaran diharapkan dapat membantu siswa secara aktif, membangun pengetahuan baru, meningkatkan pemahaman pada suatu materi, dan prestasi belajar.

Fungsi media pengajaran menurut Arsyad (2002) adalah: (1) dapat memperjelas penyampaian pesan dan informasi sehingga dapat 
memperlancar pembelajaran dan meningkatkan prestasi, (2) dapat mengarahkan perhatian siswa terhadap materi, sehingga dapat menimbulkan motivasi untuk belajar, dan (3) dapat memberikan pengalaman kepada siswa, dan dapat mengaitkannya dalam kehidupan sehari-hari.

Pemahaman matematika merupakan proses untuk menempatkan informasi atau pengetahuan yang sedang dipelajari kemudian mengaitkan dengan pengetahuan yang sudah dimiliki sebelumnya (Hiebert dan Carpenter 1992:70). Pembelajaran dengan media mobil mainan dapat membuat siswa bekerja secara aktif mem-peragakan media mobil mainan, menguji dan memberikan kesimpulan sampai mendapatkan konsep baru yang sesuai dengan model fisik atau media mobil mainan yang diberikan oleh guru.

Lima keuntungan pengajaran yang menekankan kepada pemahaman menurut Hiebert dan Carpenter (1992:74-77) ada sebagai berikut: (1) pemahaman adalah generatif, artinya siswa menciptakan pengertian internal mereka sendiri yang didapat dari interaksi dengan lingkungan dan mengaitkan dengan pengetahuan yang sudah ada sebelumnya. (2) pemahaman memacu ingatan, artinya pengetahuan yang telah dipahami dengan baik akan diatur dan dihubungkan secara efektif dengan pengetahuan-pengetahuan yang lain, sehingga pengetahuan itu lebih mudah diingat, (3) pemahaman mengurangi banyaknya hal yang harus diingat, artinya dengan memahami hubungan yang terbentuk antara pengetahuan yang satu dengan yang lain dalam struktur kognitif siswa, maka segala pengetahuan yang terkait dapat diperluas, dengan demikian siswa tidak perlu menghafalkan semuanya, (4) pemahaman meningkatkan proses perpindahan informasi, artinya pemahaman suatu konsep matematika akan diperoleh dengan menemukan kesamaan dari berbagai konsep. Hal ini akan membantu siswa untuk menganalisis apakah suatu konsep tertentu dapat diterapkan, untuk suatu kondisi tertentu, (5) pemahaman mempengaruhi keyakinan siswa, artinya pemahaman matematika yang baik akan mempunyai keyakinan positif yang akan membantu perkembangan pengetahuan matematikanya.

\section{METODE PENELITIAN}

Metode penelitian penggunaan media mobil mainan untuk meningkatkan pemahaman konsep operasi hitung bilangan bulat ini adalah Penelitian Tindakan Kelas (PTK) dengan subjek 33 siswa kelas IV SD Negeri Mojolangu 4 Malang. Model penelitian tindakan kelas yang digunakan dalam penelitian ini adalah model alur penelitian tindakan kelas yang dikembangkan oleh Kemmis dan Mc. Taggart.

Tahap-tahap penelitian ini terdiri atas (1) penetapan fokus penelitian yaitu peneliti meminta ijin penelitian, melakukan observasi awal, memberikan pretes pada siswa, memvalidasi perangkat pembelajaran dan instrumen penelitian kepada validator, dan memberika tes awal, (2) perencanaan yaitu menyiapkan dan menyusun instrumen penelitian, (3) pelaksanaan tindakan yaitu mengimple-mentasikan Rencana Pelaksanaan Pembelajaran (RPP) dengan penggunaan media mobil mainan serta mengadakan tes akhir, (4) observasi dan interpretasi yaitu merekam kegiatan pembe-lajaran siswa selama proses pemberian tindakan dan melakukan wawancara, (5) analisis dan refleksi yaitu menganalisis tingkat pemahaman konsep siswa berdasarkan jawaban siswa pada tes akhir dan menghitung skor rata-rata siswa, mendeskripsikan data dari hasil observasi dan wawancara dan merefleksi apa yang belum dilakukan dan apa perlu disempurnakan. Hasil refleksi ini akan digunakan untuk perbaikan pada siklus berikutnya.

Bentuk instrumen penelitian yang akan digunakan dalam penelitian penggunaan media mobil mainan adalah sebagai berikut: (1) soal tes, (2) lembar observasi, (3) wawancara, (4) lembar validasi.

Setelah data yang terdiri dari lembar observasi kegiatan guru, lembar observasi kegiatan siswa, hasil tes awal dan tes akhir, serta hasil wawancara sudah terkumpul, proses selanjutnya adalah melakukan analisis. Tahapan analisis data yang digunakan dalam penelitian ini terdiri dari 3 tahap yaitu (1) mereduksi data yaitu mendeskripsikan prosedur keterlaksanaan pembelajaran penggunaan media mobil-mobilan, mengelompokkan tingkat pemahaman konsep dalam penelitian ini melalui hasil tes siswa serta mengamati indikator keaktifan belajar siswa 
yang muncul selama proses pembelajaran, (2) menyajikan data yaitu membuat grafik untuk mengetahui sebaran data tentang hasil tes siswa, (3) menarik kesimpulan dan verifikasi data yaitu mengecek keberhasilan penelitian berdasarkan kriteria keberhasilan yang telah ditetapkan dan memeriksa kesalahan siswa dalam memahami konsep pada hasil tes tiap butir soal.

Peneliti selanjutnya mengadakan verifikasi atau menanyakan kepada siswa yang masih banyak melakukan kesalahan pada tes tentang letak kesalahan dan kesulitan pada tes tersebut. Pada penelitian ini penarikan kesimpulan dan verifikasi dilakukan terhadap hasil pemahaman konsep siswa pada saat tes. Kemudian hasil penarikan kesimpulan dan verifikasi ini akan menentukan perlu atau tidaknya peneliti melakukan siklus berikutnya.

Pada penelitian ini sebagai indikator peningkatan pemahaman konsep operasi hitung bilangan bulat siswa adalah apabila $\geq 75 \%$ siswa mencapai skor minimal 75 (skor tertinggi 100).

\section{HASIL DAN PEMBAHASAN}

Media mobil mainan terdiri dari mobilmobilan dan balok kayu yang berfungsi sebagai lintasannya. Balok kayu mempunyai ukuran panjang $100 \mathrm{~cm}$ dan lebar $5 \mathrm{~cm}$. Media mobil mainan ini mempunyai sisi muka dan sisi belakang agar siswa dapat membedakan arah maju dan mundur pada mobil tersebut. Pada sisi muka dengan ukuran yang sama diberi satuan bilangan bulat, misalnya ..., -5 , $4,-3,-2,-1,0,1,2,3,4,5, \ldots$. Media mobil mainan pada penelitian ini diilustrasikan pada gambar 1.

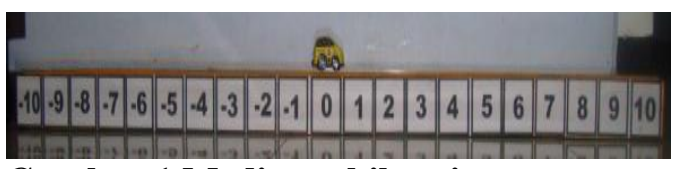

Gambar 1 Media mobil mainan

Media mobil mainan pada mempunyai petunjuk dalam penggunaannya yang dikaitkan dengan operasi hitung bilangan bulat. Petunjuk penggunaan media mobil mainan pada balok kayu ini: (1) posisi mobil pertama pada bilangan 0 dan menghadap bilangan bulat positif, (2) mobil menuju ke bilangan bulat pertama pada operasi bilangan bulat, (3) bilangan bulat positif mobil menghadap bilangan bulat positif, (4) bilangan bulat negatif mobil menghadap bilangan bulat negatif, (5) operasi penjumlahan mobil bergerak maju dan (6) operasi pengurangan mobil bergerak mundur.

Manfaat media mobil mainan ini dapat membantu siswa dalam memahami konsep abstrak pada operasi hitung bilangan bulat pada benda konkrit media mobil mainan. Tujuan penggunaan media mobil mainan pada operasi hitung bilangan bulat adalah membantu siswa dalam memahami konsep arah dan pergerakan operasi bilangan bulat pada garis bilangan. Selanjutnya setelah memahami konsep dengan media diharapkan siswa dapat mengerjakan operasi hitung bilangan bulat tanpa media. Berdasarkan manfaat dan tujuannya, penggunaan media mobil mainan ini sesuai dengan teori Piaget (Siegler dkk, 2006) yang menyatakan anak usia 7-12 tahun berada pada tahap operasional konkrit dimana anak belum bisa memahami hal yang abstrak. Konsep operasi hitung bilangan bulat ini masih bersifat abstrak dan untuk membantu mengkonkritkan digunakan media mobil mainan untuk menunjukkan pergerakan pada garis bilangan.

Secara umum, langkah-langkah pembelajaran dengan menggunakan media mobil mainan pada materi operasi hitung bilangan bulat yang dihasilkan adalah:

1. Tahap awal, guru memberikan motivasi awal dengan mengaitkan materi operasi hitung bilangan bulat dengan penjumlahan dan pengurangan bilangan cacah yang telah diperoleh sebelumnya.

2. Tahap presentasi kelas, guru mengenalkan media mobil mainan dan menyampaikan petunjuk serta contoh peragaannya. Ketika memperagakan media, guru memancing respon siswa dengan memberikan pertanyaan terkait dengan operasi hitung bilangan bulat dengan media mobil mainan yaitu (1) posisi mobil pertama berada di bilangan 0 , kemudian mobil bergerak ke bilangan berapa, (2) selanjutnya mobil mengahadap kemana dan bergerak berapa satuan, (3) posisi mobil terakhir berada di bilangan berapa, (4) bagaimana penulisan kalimat matematika dari peragaan tersebut? Jawaban siswa adalah "posisi mobil pertama di bilangan 0 kemudian bergerak ke bilangan 3. Kemudian mobil mengahadap bilangan negatif dan mundur 
7 satuan. Posisi mobil terakhir berada di bilangan 10. Jadi $3-(-7)=10$ ".

3. Tahap diskusi, siswa membentuk kelompok belajar. Pada tahap ini siswa menggunakan media mobil mainan untuk memahami konsep operasi hitung bilangan bulat dengan menyelesaikan kegiatan yang ada pada LKS. Siswa memperagakan sendiri media mobil mainan, kemudian menuliskan pergerakannya dan memperoleh hasil akhir. Guru berkeliling melihat pekerjaan siswa dan membantu mengarahkan siswa apabila mengalami kesulitan. Soal kegiatan pada LKS: Selesaikanlah operasi hitung bilangan bulat berikut dengan menggunakan media mobil mainan.

a. $5+(-8)$ dan $5-8$

b. $4-(-5)$ dan $4+5$

Siswa mempresentasikan hasil diskusi pada kegiatan yang telah dikerjakan dengan memperagakan menggunakan media mobil mainan.

4. Tahap akhir, guru membimbing siswa untuk memberikan kesimpulan. Setelah siswa mempresentasikan hasil diskusi, guru membimbing siswa untuk memberikan kesimpulan bahwa $a+(-b)=a-b$ dan $a-(-b)=a+b$

Tahapan yang telah dirancang secara garis besar sesuai dengan tahapan perkembangan berfikir siswa yang dinyatakan oleh Bruner (1965:11) yaitu (1) Enactive, pada tahap ini anak-anak belajar dengan menggunakan atau memanipulasi media mobil mainan secara langsung. Anak memperagakan dan menjalankan media mobil mainan, (2) Ikonic, pada tahap ini kegiatan anak mulai mengait-kan mental yang merupakan gambaran dari objek. Siswa mentranslasi pergerakan media mobil mainan ke dalam symbol angka pada garis bilangan diluar media mobil mainan dan (3) Symbolic, pada tahap ini merupakan tahap memanipulasi simbol-simbol secara langsung. Siswa telah mampu menggunakan notasi untuk menyelesaikan operasi hitung bilangan bulat.

Penggunaan media mobil mainan ini dapat membantu siswa dalam memahami konsep operasi hitung bilangan bulat yaitu siswa dapat menggambarkan operasi hitung bilangan bulat dengan media atau garis bilangan, mengubah dari pergerakan menggunakan media atau garis bilangan ke kalimat matematika dan kemudian siswa dapat mengerjakan operasi hitung bilangan bulat tanpa menggunakan media mobil mainan.

Langkah-langkah pemahaman konsep operasi hitung bilangan bulat dengan menggunakan media mobil mainan sejalan dengan Hiebert dan Carpenter (1992:70) yaitu (1) pemahaman adalah generatif, siswa dapat mengaitkan materi operasi penjumlahan dan pengurangan bilangan bulat dengan materi yang telah didapatkan sebelumnya yaitu penjumlahan dan pengurangan bilangan cacah.

(2) pemahaman memacu ingatan, penggunaan media mobil mainan dapat membantu siswa untuk mengingat konsep operasi hitung bilangan bulat. (3) pemahaman mengurangi banyaknya hal yang harus diingat, siswa memberikan kesimpulan terhadap materi berdasarkan kegiatan yang telah dilakukan sehingga siswa dapat mengurangai banyaknya rumus untuk diingat. (4) Pemahaman meningkatkan proses perpindahan informasi, artinya siswa dapat mengaitkan materi operasi penjumlahan dan pengurangan bilangan bulat dalam kehidupan sehari-hari, sehingga dapat menyelesaikan soal dengan mudah.

Pemahaman siswa tentang konsep operasi hitung bilangan bulat sangat baik. Hal ini terlihat berdasarkan hasil tes akhir siswa. Tes akhir siswa dilaksanakan dengan tujuan untuk mengetahui tingkat pemahaman konsep siswa terhadap materi operasi hitung bilangan bulat dan untuk mengetahui keberhasilan siswa. Tes akhir dilakukan pada akhir siklus I dan siklus II yang dikerjakan siswa secara individu. Soal tes akhir yang diberikan terdiri dari 10 soal uraian. Adapun kriteria khusus bahwa pemahaman konsep siswa dikatakan meningkat jika $\geq 75 \%$ siswa mencapai nilai KKM 75 (skor tertinggi 100).

Berdasarkan hasil tes akhir, diperoleh data yaitu

1. Pada siklus I sebanyak 24 siswa atau $72 \%$ siswa yang memperoleh nilai KKM (Kriteria Ketuntasan Minimal) yaitu 75.

2. Pada siklus II sebanyak 29 siswa atau $88 \%$ siswa yang memperoleh nilai KKM (Kriteria Ketuntasan Minimal) yaitu 75.

\section{SIMPULAN DAN SARAN}

Berdasarkan penelitian yang telah dilakukan mengenai penggunaan media mobil mainan untuk meningkatkan pemahaman 
konsep operasi hitung bilangan bulat siswa kelas IV SDN Mojolangu 4 Malang dapat disimpulkan bahwa penggunaan media mobil mainan meliputi 4 langkah yaitu tahap awal, presentasi, diskusi dan akhir. Pada tahap awal, guru memberikan motivasi awal dengan mengaitkan materi operasi hitung bilangan bulat dengan materi yang telah diperoleh sebelumnya, presentasi kelas guru menyampaikan petunjuk serta contoh peragaan dengan menggunakan media mobil mainan, diskusi, pada tahap ini siswa menggunakan media mobil mainan untuk memahami konsep operasi hitung bilangan bulat dengan menyelesaikan kegiatan yang ada pada LKS, tahap akhir guru membimbing siswa untuk memberikan kesimpulan.

Penggunaan media mobil mainan dapat meningkatkan pemahaman konsep operasi hitung bilangan bulat. Hal ini terlihat dari peningkatan hasil tes pemahaman konsep dari siklus I ke siklus II, yaitu Pada siklus I sebanyak 24 siswa atau $72 \%$ siswa yang memperoleh nilai KKM (Kriteria Ketuntasan Minimal) yaitu 75 dan pada siklus II sebanyak 29 siswa atau 88\% siswa yang memperoleh nilai KKM (Kriteria Ketuntasan Minimal) yaitu 75 .

Saran dari kegiatan yang telah dilaksanakan dalam penelitian ini, hendaknya dapat melakukan penelitian lebih lanjut tentang media lain yang dapat meningkatkan pemahaman konsep pada mata pelajaran matematika.

\section{DAFTAR RUJUKAN}

Arysad, A. 2002. Media Pembelajaran. Jakarta: Raja Grafindo Persada.

Bruner, J. 1965. Toward a Theory of Instruction. Cambride: Harvard University Press.

Depdiknas, 2007. Kajian Kebijakan Kurikulum Mata Pelajaran Matematika. Jakarta: Badan Penelitian dan Pengembangan Pust Kurikulum.

Hiebert, J \& Carpenter, T. P. 1992. Learning \& Teaching with Understanding. Dalam D. A. Graws (Eds). Handsbook of Research on Mathematics Teaching \& Learning.
New York: Mcmillan Publishing Company.

Muhsetyo, dkk. 2007. Pembelajaran Matematika SD. Jakarta: Universitas Terbuka.

Musher, G.L. \& William, F.B. 1991. Mathematics For Elementary Teachers : A Contemporary Approach $-2^{\text {nd }}$. New York: Macmilan Publishing Company

Sadiman, A.S. 2008. Media Pendidikan. Jakarta: Rajawali Pres.

Siegler, dkk. 2006. How Children Development. New York: Word Publishers.

Swan \& Marshal. 2010. Revisiting Mathematics Manipulative Materials. Jurnal Gale, (Online), 15 (2): 13-19. (http://infotrac.galegroup.com/itweb), diakses 8 Juni 2012. 